\title{
DYNAMICS OF PRODUCTIVITY OF RESTORED VEGETATION OF THE IZYKHSKY SURFACE MINE (TERRA MODIS)
}

\author{
Alexander Zhukov ${ }^{1 *}$, Elena Zhukova ${ }^{1}$ \\ ${ }^{1}$ Graduate student, candidate of Biological Sciences, Federal State-Funded Educational Institution of \\ Higher Education «Katanov State University», 655017, Lenin Avenue 90, Abakan, Russia
}

\begin{abstract}
The subject of the study is the course of the dynamics of vegetation productivity on the dumps of the surface mine «Izykhsky» (2000-2019), using Terra Modis. The aim is to identify patterns of seasonal and long-term dynamics of restored vegetation as a result of succession according to images. The methodology included processing information on gross primary production and evapotranspiration, as well as identifying the relationship with meteorological data for 2018-2019. There is a positive trend in the long-term dynamics - in terms of total gross primary production from 1.7 to $5.5 \mathrm{~kg} / \mathrm{m}^{2} / 8$ days and in evapotranspiration from 1142 to $2784 \mathrm{~kg} / \mathrm{m}^{2} / 8$ days. The evapotranspiration correlated with the productivity. Since 2016, productivity has reached a plateau, which indicates the development of ecological niches by plants. The phytomass of the restored vegetation was in 1.5 times greater, than the mass of the steppe site. Seasonal dynamics in 2019 showed that communities on dumps have higher productivity, in contrast to the steppe, and one peak in the first ten days of July. The sum of temperatures and productivity had a high relationship $\left(\mathrm{R}^{2}=0.7\right)$ in comparison with the steppe $\left(\mathrm{R}^{2}=0.2\right)$. Terra Modis data can be applied in the field of ecological monitoring of vegetation of coal dumps.
\end{abstract}

A monitoring of restored lands, the vegetation cover disturbances and the pollution is carried out also according to remote sensing data $[1,2]$. The coal industry in Khakasia has increased dramatically since 2015 ( 7 surface mines, 5222 hectares of disturbed territories) [2]. Vegetation reconstruction efforts were becoming increasingly difficult in the areas affected by coal mining. The lack of moisture, high temperatures, with a short period of temperatures above $10^{\circ} \mathrm{C}$ leads to the fact that organic matter have started to mummify for a long time, and not its decomposition $[3,4]$.

The aim of the work is to identify patterns of seasonal and long-term dynamics of vegetation productivity as a result of succession after reconstruction of the Izykhsky surface mine (Khakasia) according to Terra Modis data.

For that purpose, it has been using Terra Modis data from the site https://lpdaacsvc.cr.usgs.gov/appeears: 1) gross primary production (GPP) [5], 2) evapotranspiration [6] (artifacts were replaced by the arithmetic mean from adjacent composites).

The sum of temperatures was obtained from the site rp5.ru. For integral productivity and evapotranspiration (half-sum of bases, multiplied by 8 days of the composite), the sum and standard deviation were calculated, and the regression was additionally calculated (Excel).

The Izykhsky coal surface mine has been developed since the 1960s. During this time, the natural landscape was transformed into the mining one in the form of a residual

\footnotetext{
* Corresponding author: zhukov.khsu@gmail.com
} 
quarry and an external coal dump on the land surface of 131 and 322 hectares, respectively (Fig. 1). In the 2000s. its reclamation has begun [1].

The climate is continental, the radiation balance is $33-34 \mathrm{kcal} \mathrm{per} \mathrm{cm}^{2}$, water $(65 \%)$ is spent on evaporation. The sum of temperatures for the warm season is $1800-1950^{\circ} \mathrm{C}$. The amount of precipitation is $320 \mathrm{~mm}$ [3].

Chestnut soils, common or southern chernozems are widespread [3]. The layer up to $2 \mathrm{~m}$ is formed by Quaternary rocks. Humus in a layer up to $40 \mathrm{~cm}$ is $1.5-3.4 \%$ [1]. The evolution of steppe soils on coal dumps has been stopping for a long time only on the organo-accumulative stage, less often on the sod stage [7]. Due to the lamellar shape and angularity of embryozems, soil compaction occurs [4]. Erosion, deflation and aeolian weathering in the dry steppe zone can lead to a desertification and impeded a recovery [8].

There were Artemisia glauca Pall. ex Willd., A. sieversiana Willd., Calamagrostis epigeios (L.) Roth, Cirsium setosum (Willd.) Bess., Elytrigia repens (L.) Nevski, Glycyrrhiza uralensis Fisch. Hieracium umbellatum L., Hordeum jubatum L., Kitagawia baicalensis (I. Redowsky ex Will.) Pimenov, Medicago falcata L., Melilotus albus Medik., Melilotus officinalis (L.) Pall., Poa pratensis L., Sonchus arvensis L., etc. [1].

In 2020, ground-based studies of the shallow sod steppe (1 contour), vegetation on the southern (2), western (3) and northern (4) parts of the dump were carried out (Fig.1).

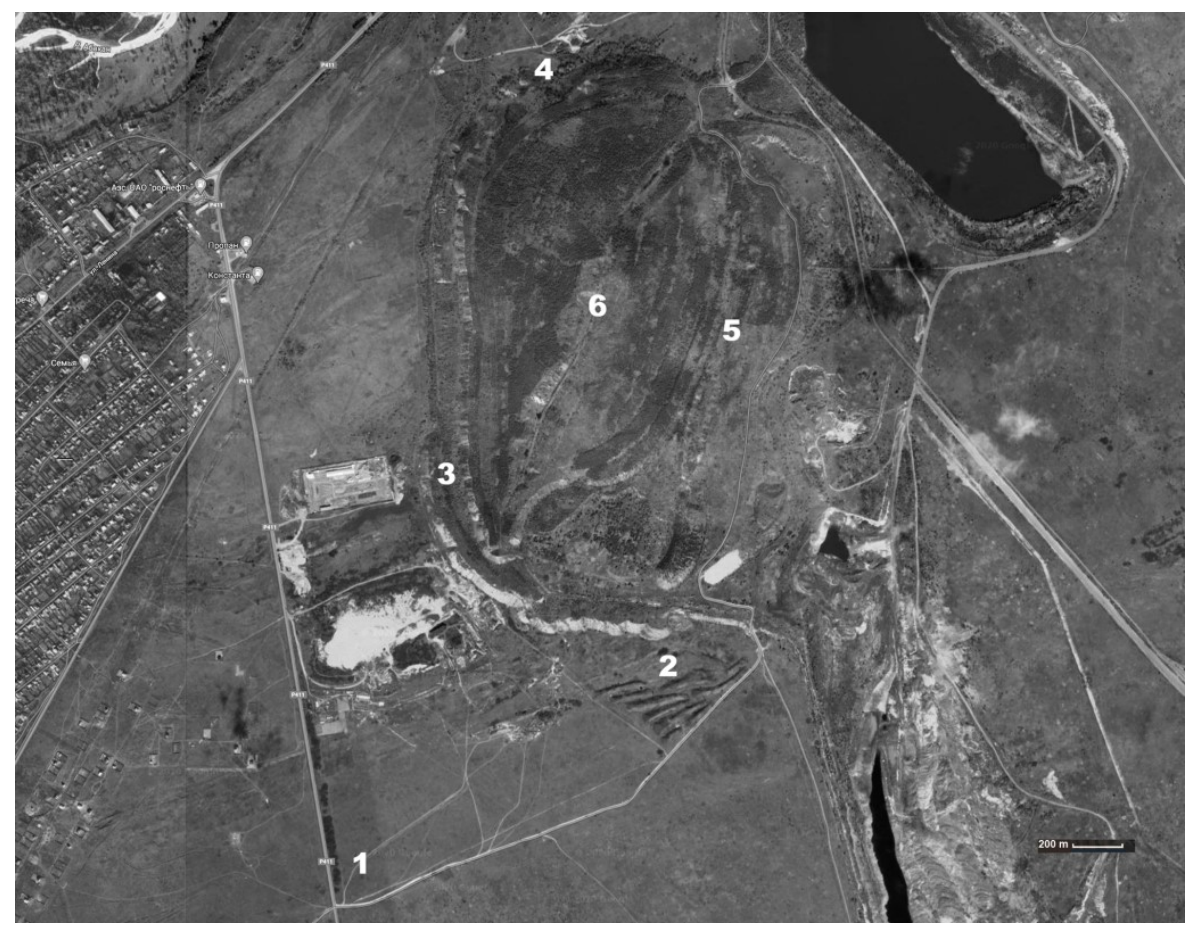

Fig. 1. Scheme of the Izykhsky coal dump: 1 - steppe $\left(53.5943298^{\circ}\right.$ and $\left.91.42101288^{\circ}\right), 2$ - southern part $\left(53.60325623^{\circ}\right.$ and $\left.91.43474579^{\circ}\right), 3$ - western part $\left(53.61053467^{\circ}\right.$ and $\left.91.43690872^{\circ}\right), 4-$ northern part $\left(53.61527252^{\circ}\right.$ and $\left.91.43182755^{\circ}\right), 5$ - eastern part $\left(53.61808777^{\circ}\right.$ and $\left.91.44054794^{\circ}\right)$, 6 - central part of the dump (53.61080933 ${ }^{\circ}$ and $\left.91.42228317^{\circ}\right)$ (Google map, 1:200)

The steppe has a projective cover $-60 \%$. The aspect of the steppe area is yellowgreen with dove-colored spots of Artemisia frigida Willd. A simple two-level structure of the grass stand was noted with dominants in the first level - Koeleria macrantha (Ledeb.) Spreng. (30\%) and in the second Artemisia frigida (20\%) and Potentilla acaulis L. (5\%). Of other species, there are Artemisia scoparia Waldst. et Kit., Astragalus danicus Retz., 
Buglossoides arvensis (L.) I.M. Johnston, Chamaerhodos erecta (L.) Bunge, Elytrigia repens, Galatella angustissima (Tausch) Novopokr., Galium verum L., Koeleria glauca (Spreng.) DC., Leymus angustus (Trin.) Pilg., Melilotus officinalis, Onobrychis arenaria (Kit. ex Willd.) DC., Otites wolgensis (Hornem.) Bess. ex Spreng., Oxytropis pilosa (L.) DC., Poa angustifolia L., Potentilla longifolia Willd. ex Schlecht., Thymus minussinensis Serg., Veronica incana L. etc.

In the southern part, the projective cover is much higher (85\%), the aspect is green, the structure of the herbage is three-level - Ulmus pumila L. (20\%) prevails in the first layer, Artemisia sieversiana (7\%), Cirsium setosum (7\%), Calamagrostis epigeios (20\%) and Artemisia frigida (10\%). Other species included Artemisia scoparia, Artemisia vulgaris L., Astragalus melilotoides Pall., Atriplex prostrata Boucher ex DC. , Bromopsis inermis (Leyss.) Holub, Calamagrostis epigeios, Cynoglossum officinale L., Festuca rubra L., Festuca valesiaca Gaudin, Glycyrrhiza uralensis, Hordeum jubatum, Lactuca sibirica (L.) Benth. ex Maxim., Lactuca sibirica, Lappula squarrosa (Retz.) Dumort., Lepidium latifolium L., Melilotus officinalis, Otites wolgensis, Poa angustifolia, Rumex crispus L., Spiraea media Franz Schmidt, Stipa capillata L., etc. Spectral analysis shows that the southern and eastern slopes, as well as the western and central areas, have a similar species composition, but different projective cover.

The western part of the dump has a significant projective cover of $80 \%$, and a variegated aspect (green with yellow spots of flowering Melilotus officinalis, purple flowers of Cirsium setosum and blue flowers of Lactuca sibirica. The structure of the community becomes more complicated up to 3 levels - Ulmus pumila dominates in the first level $(10 \%$, in places up to 20\%), the second one is polydominant (Calamagrostis epigeios (20\%), Poa pratensis (10\%), Cirsium setosum (7\%), Melilotus officinalis (5\%)), in the lowest one there is a moss cover (30\%). Poa angustifolia, Erigeron acris L., Rumex crispus, Taraxacum bessarabicum (Hornem.) Hand.-Mazz., Sonchus oleraceus L., Melilotus albus, Hordeum jubatum, Artemisia sieversiana are also found here.

In the northern part of the dump, trees and shrubs are well developed, in addition to Ulmus pumila, there are Acer negundo L., Cotoneaster melanocarpus Fisch. ex Blytt., Populus laurifolia Ledeb., Padus avium Mill., Betula pendula Roth, Pinus sylvestris L. The total projective cover is $65 \%$, in some places up to $80 \%$. Aspect - green with blue spots Lactuca sibirica. Two levels were recorded - Ulmus pumila (20\%) prevails in the first, Poa pratensis (10\%), Cirsium setosum (10\%), Calamagrostis epigeios $(10 \%)$ prevail in the second. Accompanying species include Agrimonia pilosa Ledeb., Arctium leiospermum (Juz.) et C. Serg., Artemisia vulgaris, Centaurea stoebe L., Cynoglossum officinale L., Elytrigia repens, Erigeron acris, Festuca valesiaca, Galium verum L., Geranium sibiricum L., Geum aleppicum Jacq., Glycyrrhiza uralensis, Helictotrichon desertorum (Less.) Nevski, Hieracium umbellatum, Kitagawia baicalensis, Linaria acutiloba Fisch. ex Rchb., Poa angustifolia, Potentilla longifolia, Scabiosa ochroleuca, Sonchus arvensis, Stipa pennata L., Taraxacum bessarabicum, Vicia cracca L.

From the point of view of studying of successions, the Terra Modis data are of interest primarily due to their significant archive (Fig. 2).

There are 3 peaks in 2003, 2014 and 2018, as well as declines in 2002, 2005, 2013 and 2015. The steppe has the smallest phytomass (Koeleria macrantha, Artemisia frigida, Poa angustifolia, Potentilla acaulis) and is characterized by stability in development, more resistant to unfavorable weather conditions, which is clearly marked in 2002 and 2005. There is a positive trend for all sites, especially for the eastern, northern and central parts.

High performance coincides with ground data. Evapotranspiration correlates with productivity (Fig. 3).

In the central part, evapotranspiration ranked first due to the accumulation of water (physical evaporation). 


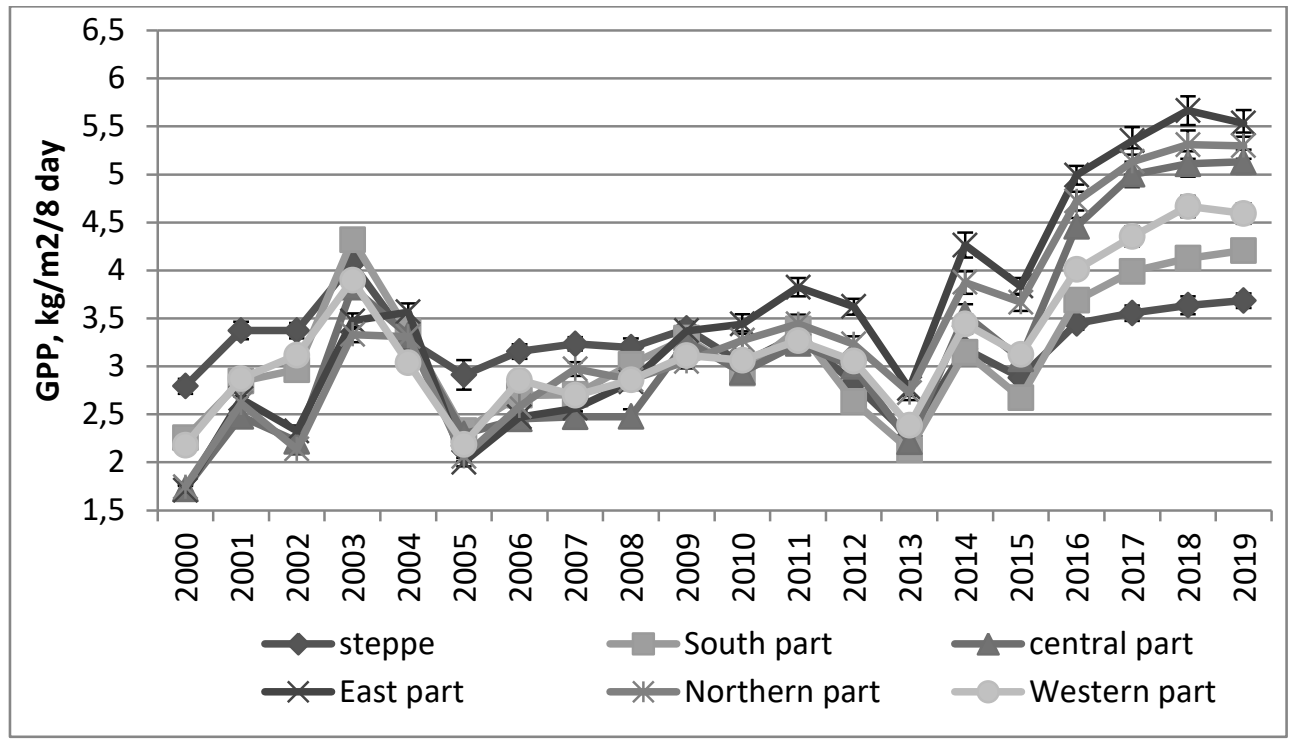

Fig. 2. The total gross production of the plant communities of the Izykhsky coal dump (2000-2019)

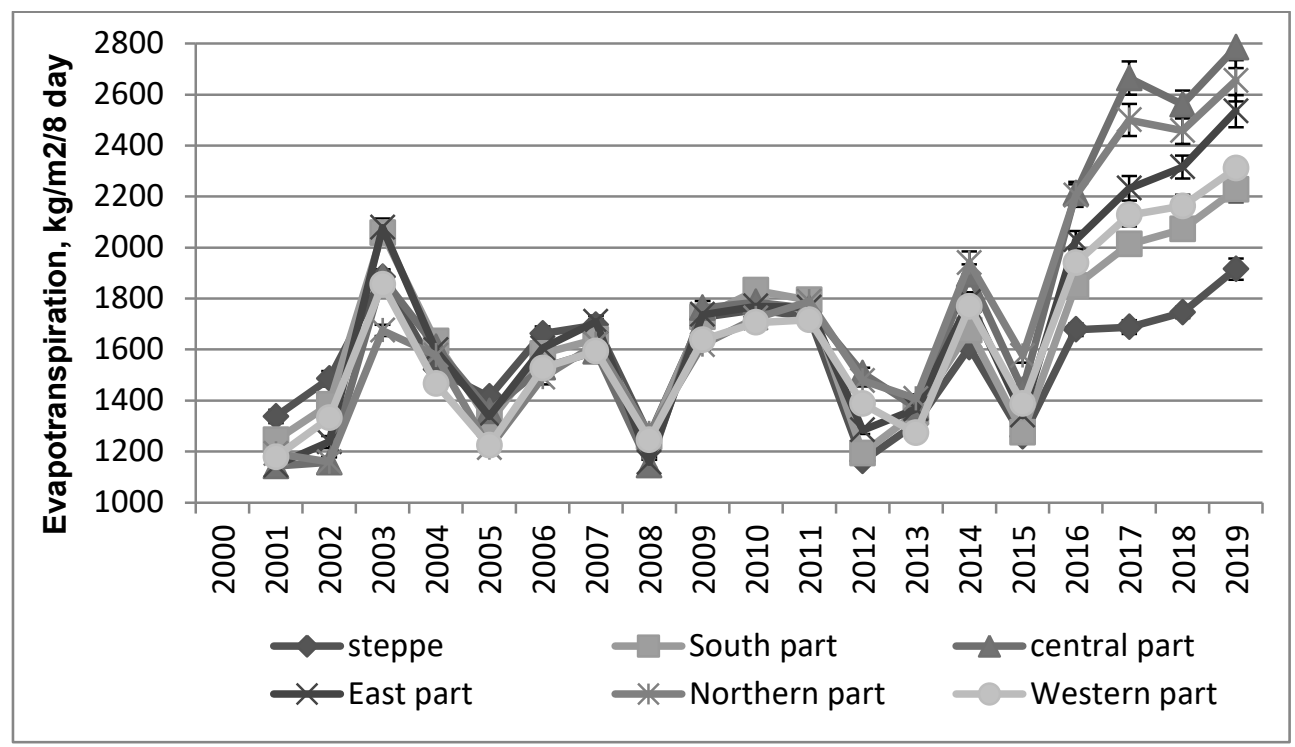

Fig. 3. The total evapotranspiration of plant communities of the Izykhsky coal dump in the period from 2000 to 2019

Consider the seasonal dynamics for 2019 (Fig. 4).

In contrast to the steppe with low productivity, the phytocoenoses on the dumps had a high productivity and a peak coinciding with the temperature peak. The maximum values were observed in the eastern and northern parts, the minimum values were in the south, where herbaceous vegetation is widespread.

The dependences of the GPP indicator on the sum of positive temperatures (regression) for the vegetative season from 2018 to 2020 were studied. The results showed that natural vegetation has a weak positive dependence on the sum of temperatures $\left(\mathrm{R}^{2}=\right.$ $0.16,4$ degree polynomial). This shows that the vegetation of such communities is better adapted from the point of ecological view to the semiarid climate. 


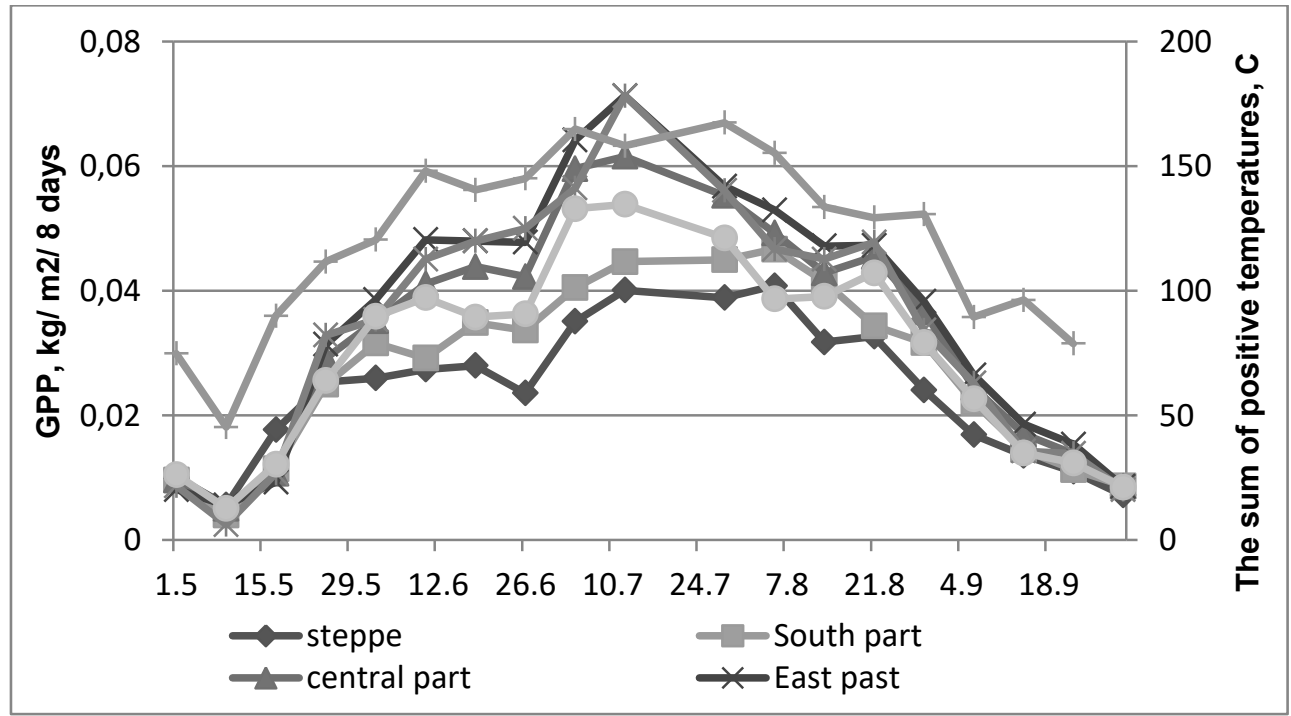

Fig. 4. Seasonal dynamics of plant communities of the Izykhsky coal dump in 2019

We list the indicators of the coefficient of determination for the polynomial equation of the 3rd degree - for the southern and western parts of 0.73 and 0.74 , for the central, eastern and northern parts -0.77 , respectively; 0.75 and 0.77 .

Consequently, the coal dump vegetation is more dependent on meteorological conditions than the steppe background

During the work, the following conclusions were made:

1. There is a positive trend - in terms of total gross primary production from 1.7 to $5.51 .7 \mathrm{~kg} / \mathrm{m}^{2} / 8$ days and for evapotranspiration from 1142 to $2784 \mathrm{~kg} / \mathrm{m}^{2} / 8$ days in the long-term dynamics of Terra Modis satellite data in the period from 2000 (2001) to 2019. The dynamics of evapotranspiration correlates with gross productivity in general. Since 2016, the GPP index has reached a plateau, which indicates the closure of the vegetation cover and the occupation of accessible ecological niches by plants.

2. The GPP parameter for the restored vegetation was 1.5 times higher than the natural steppe vegetation. Consequently, for plants on the coal dump, in general, the growing conditions (moisture, nutrients) are favorable. This is confirmed by a higher projective cover and larger sizes of species. This makes the territory promising for the restoration of biological diversity, even for trees and shrubs.

3. The analysis of seasonal dynamics for 2019 showed that, in contrast to the steppe community, the communities on the restored coal dumps had high productivity (up to 0.07 $\mathrm{kg} / \mathrm{m}^{2} / 8$ days) and one peak of the seasonal development in the first ten days of July. The maximum values throughout the season were observed in the more humid eastern and northern parts of the coal dump, and the minimum values were in the southern part.

4. Regression analysis showed that GPP and the sum of positive temperatures had a high level of relationship $\left(\mathrm{R}^{2}=0.7\right)$ compared to the steppe site $\left(\mathrm{R}^{2}=0.2\right)$.

\section{References}

1. O.A. Berezina, A.N. Shikhov, R.K. Abdullin The use of multi-temporal satellite images for environmental assessment in coal mining areas (by example of closed Kizel coal basin) // Current problems in remote sensing of the Earth from space, 15 (2), 144-158 (2018) 
2. L.V. Zenkov, B.N. Nefedov, Yu. P. Yuronen, N.B. Nefedov Environmental condition remote soundining and field surveys of the lands, disturbed by coal mining open pits in the republic of Khakassia //Coal, 9, 72-75 (2017)

3. Kuminova A.V. et al. Vegetation cover of Khakasia. Novosibirsk: Science, Siberian Branch RAS, 127 p. (1976)

4. E.A. Gurkova, D.A. Sokolov, S.P. Kulizhsky, S.V. Loiko Micromorphological peculiarities of soils in technogene landscapes of coal-mine industries in Siberia (Russia) // Novel methods and results of landscape research in Europe, Central Asia and Siberia, 27-31 (2018)

5. Running S., Mu Q., Zhao M., MOD17A2H. doi: 10.5067 (2015) (date 25.11.2018).

6. Running S., Mu Q., Zhao M. (2017). Terra Net Evapotranspiration. MOD16A2.006. doi: 10.5067 (date 25.11.2018).

7. D.A. Sokolov, S.P. Kulizhsky, S.V. Loiko, E.A. Domozhakova Using electronic scanning microscopy for diagnostics of soil-forming processes on the surface of coalmine dumps in Siberia// Tomsk State University Journal of Biology, 3, 36-52 (2014)

8. Balyazin I.V. Influence of the coal industry on the ecological condition of the Koybalskaya steppe // Geographical Research of Asian Russia and Adjacent Territories: New Methods and Approaches, 28-32 (2019) 